\title{
避難所における避難者が実施した衛生的な行動と感染予防対策
}

\author{
岡田 淳子1）·山水有紀子2） · 山根 啓幸 ${ }^{3)} \cdot$ 山村 美枝1) \\ 松本 由恵 ${ }^{1)}$ ·百田 武司 ${ }^{1)} \cdot$ 西條 美恵 ${ }^{4)} \cdot$ 板橋 美絵 4$)$
}

\section{Infection Prevention Measures and Hygiene Precautions Among Evacuees in Emergency Shelters}

Junko OKAdA ${ }^{1)}$, Yukiko YamamizU ${ }^{2)}$, Hiroyuki Yamane ${ }^{3)}$, Mie YAmamura ${ }^{1)}$, Yoshie Matsumoto ${ }^{1)}$, Takeshi Hyakuta ${ }^{1)}$, Mie SAijo ${ }^{4)}$ and Mie Itabashi ${ }^{4)}$

1) Department of Nursing, Japanese Red Cross Hiroshima College of Nursing,

${ }^{2)}$ Clinical Safety Management Office, Hiroshima Red Cross Hospital \& Atomic-bomb Survivors Hospital,

3) Infection Control and Prevention Room, Shobara Red Cross Hospital,

${ }^{4)}$ Department of Nursing, Japanese Red Cross Ishinomaki Hospital

(2014 年 4 月 8 日 受付 $\cdot 2014$ 年 9 月 1 日 受理)

要旨

大規模な災害時は生命の危機状態にある患者が急増し，医療機関は入院患者の対応が優先される ため避難所への支援は困難になる，そのため，避難所での感染伝播を防ぐには，避難者が実施する 衛生管理が重要になる．そこで，避難者が実施した衛生的な行動を明らかにし，避難所の感染予防 策について検討した.

東日本大震災で避難所生活を経験した避難者 80 名を対象に, 手指衛生と環境衛生について構成 的面接を実施した。その結果, 震災直後は手を洗う環境が全くなかったと約 $60 \%$ が回答したが, 救援物資の到着や水道の復旧によって手指衛生は強化された. しかし, 手指衛生の実施場面は個人 の衛生習慣が影響するため, 日常から住民の手指衛生が習慣化する関わりが必要と思われる. ま た，外部支援による感染予防行動や衛生管理の指導は約 $25 \%$ の避難者にしか認識されていなかっ た.しかし, 指導を受けた避難所リーダーが感染予防行動を具体的に指示した避難所は, 環境の衛 生状態を維持していた。避難所で感染を防止するためには, 集団をマネジメントするリーダーの存 在が重要であり，外部支援としては避難者らが予防行動を開始できるように支援することが示唆さ れた.

Key words : 避難所, 避難者, 手指衛生, 衛生的な行動, 感染予防

\section{はじめに}

2011 年 3 月 11 日に発生した東日本大震災では多く の住民が津波で住居を失い, ライフラインの停止によっ て避難所での生活を余儀なくされた．避難所には小児か ら高齢者まで，健康状態の異なる地域住民が一斉に駆け つけ，密集した生活空間のなかで衛生設備を共有する. そして, 被害の程度が大きいほど, 避難所での生活は長 期化し, 衛生状態を維持しなければ避難者は感染症を発

1) 日本赤十字広島看護大学看護学部, ${ }^{2}$ 広島赤十字 - 原爆病院 医療安全推進室, ${ }^{3}$ 庄原赤十字病院感染制御室, ${ }^{4)}$ 石巻赤十字 病院看護部
症する．その結果，感染症が避難所に夢延する可能性が ある。

宮城県石巻市では, 震災から約 10 日目の調査によっ て, 約 300 力所の避難所のうち約 3 割のトイレに衛生 上の問題があると判明し, 看護師が巡回を開始した1).

トイレなどの衛生問題は岩手県でも発生し, 岩手県保健 福祉部医療推進課が所轄となり，感染制御支援チームを 派遣した．支援チームは避難所を訪問し携帯端末から感 染上の問題や感染症発生などのデータを送信して, 必要 に応じて診療や支援を行った ${ }^{2)}$ 。また, 震災後 2 ヶ月が 経過した避難所では呼吸器感染症や急性胃腸炎の集団発 
生が疑われ, 医師や保健師らが感染予防策の強化や衛生 指導を行った ${ }^{3)}$. このように, 医師や看護師, 保健師ら 医療職者が避難所での感染症の発生状況を把握し, 手指 衛生の方法, トイレ清掃, ゴミや污物処理などの指導を 行い, 衛生材料の配給やポスター掲示など集団に向けた 感染症の発症予防と拡大防止のための対応を行っていた。

しかし, 大規模な災害時, 医療機関では生命の危機状 態にある入院患者の対応が優先され，避難所に対しては 少数の医療者で支援にあたることになる. そのため, 避 難所での感染症の発症および感染伝播を減らすためには 避難所のスタッフと避難者が適切な感染対策を行うこと が重要になる4)。すなわち，避難者は手指衛生，うがい やマスク着用などの感染予防行動を個々に実施する必要 がある、しかし, 本災害に括いて, 避難者が避難所で実 際にどのような衛生管理を行っていたかは明らかになっ ていない.

そこで，避難者が実施していた衛生的な行動を明らか にし，避難所で感染伝播を防ぐ対策を検討する.

\section{研 究方法}

\section{1. 対象}

東日本大震災で被災し避難所生活を経験した宮城県内 の仮設住宅または自宅で生活している避難者で, 同意が 得られた 80 名を調査対象者とした.

\section{2. 調査方法}

調査時期は震災後 2 年が経過した 2012 年 9 月〜 2013 年 3 月である.

仮設住宅自治連合推進会事務局長へ研究の目的と方法 を口頭と文書で説明し, 調査当日に健康相談会を開催し たあと, 調査を実施することで承諾を得た. その後, 事 務局長が仮設住宅自治会長会議の場で自治会長に研究依 頼について説明した。任意で了承した自治会長 6 名が それぞれの仮設団地で，住民へ健康相談および調查日時 を記載したポスターを配布し，呼びかけを行った。

調査当日, 調査者 5 名が仮設団地の集会所に待機 し, 来場した住民に健康相談会を開催した. その後, 調 查者は研究の目的と方法を文書と口頭で説明し, 同意が 得られた住民を対象に, 質問紙に沿って 1 人ずつ構成 的面接を行った。仮設住宅住民の他に, 仮設住宅の管轄 部署を通して紹介された避難者に研究の目的と方法を説 明し，同意を得て実施した。

\section{3. 調査内容}

調査は避難所での手指衛生と環境衛生について, 著者 らが独自に作成した質問紙を用いて行った。手指衛生に 関しては震災直後と救援物資到着後それぞれの時期で, 8 つの実施場面 (起床時, 食事前. 後, 排泄後, 片付 後, 炊出前, 掃除後, 就寝前) を示し, 各場面での手指 衛生の具体的な方法を聞き取った. 同時に手指衛生の実
施頻度を「 $0=$ できない， $1=$ 時々できた， $2=$ できた」 の 3 段階で評価してもらった．環境衛生に関しては， 居住スペースとトイレの清掃および換気の実施の有無を 確認し，避難所の環境衛生と実施した対策は体験したこ とを話してもらい，発言をそのまま記録した．さらに， 感染予防に関連する外部支援の有無とその内容を確認し た。そして, 個人の感染予防対策は手指衛生, マスク着 用，予防接種の実施の有無を被災前後で確認した。

\section{4. 分析方法}

調查結果は，統計ソフト SPSS Statistics 17.0 を用い て統計処理を行った。手指衛生は実施場面毎に頻度を得 点化して平均值で示し, 震災直後と物資到着後の手指衛 生の方法を記載し, 物資到着後は回答数も示した.さら に，居住スペースとトイレの清掃および換気については 実施人数を示した．個別の感染予防対策は Wilcoxon 符 号順位検定を用いて被災前後を比較した．被災時の手指 衛生, 環境衛生とその管理に関することは対象者の発言 内容を変えずに記載した.

\section{5. 倫理的配慮}

仮設住宅の集会所を訪れた住民に対して，研究目的を 文書と口頭で説明し, 調査への協力は自由意思に基づく ものであり，拒否あるいは調査途中で協力を中止しても よいことを伝え，どんな場合でも不利益を受けないこと を説明した。 また，調査で得られた情報は，厳重に管理 し, プライバシーを厳守すること, 研究終了後は, 確実 に収集した情報を破棄することを説明した。ささに，研 究結果は個人を特定できないようにプライバシー保護の 上で看護関連学会にて公表することを加え, 了解を得ら れた場合，同意書に自署してもらった．

なお, 本研究は日本赤十字広島看護大学研究倫理委員 会の承認(審査番号：1213)を得て行った.

\section{結果}

調査対象者 80 名のうち, 震災後 24 時間以内にライ フラインの整備された地域に避難した 7 名を除く避難 者 73 名を分析対象とした. 分析対象者の平均年齢は $66.6 \pm 15.0$ 歳で, 男性 14 名, 女性 56 名, 不明 3 名で あった. 分析対象者 66 名は石巻市, 6 名は山元町, 1 名は名取市の避難所で避難生活を送った者であった。

\section{1. 手指衛生}

震災直後からウェットティッシュやアルコール手指消 毒剤を使用していたと回答した避難者はいたが，震災直 後は手指衛生を実施する環境が全くなかったと46名 (63.0\%) が回答した．そのうち 13 名は救援物資の届く 前に避難所を退所し，14 名は水道が復旧して手指衛生 を実施できたと回答した。しかし，「物資は飲み水だけ で手指衛生はできなかった」という発言があり，避難所 によっては救援物資が届けられても, 飲料水が優先でウ 
エットティッシュやアルコール手指消毒剤での手指衛生 にとどまっていた（表 1)。 また，「井戸水や沢の水を利 用していた」，「給水車の水を小分けにして使用した」, 「手指消毒剤を配給されても使用していなかった」など

\section{表 1 物資到着後の手指衛生方法の変化}

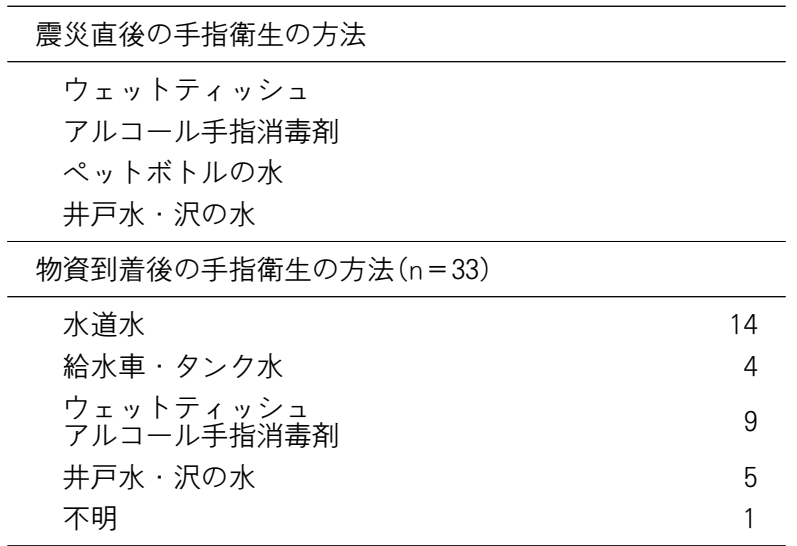

$\mathrm{n}$ : 手指衛生を実施する手段がなかった避難者 46 名のうち, 物資到着まで避難所に滞在していた 33 名.

\section{表 2 水道が復旧するまでの手指衛生に関する避難者の発言}

手がベタベタで, 歯みがきを忘れていた

流れてきたペットボトルの酒などで手を洗った

井戸水を手洗いとトイレに使用した

山水をホースで使用した

中学校の沢の水をホースで使用した

自衛隊が来てから手を洗った

顔は沢の水で洗い, 2 週間後, 水道が復旧した

給水所の水を風呂に溜め小分けに使用した

手指消毒を配布されていたが使用しなかった

物資でもらった手指消毒剂を使用した
（表 2)，水道が復旧するまでの手指衛生については，積 極的に実施されていなかった.

手指衛生を実施する場面は，いずれの場面においても 物資到着後の方がその実施頻度は高かった。しかし，食 事前, 排泄後に比べ，その他場面では頻度は低い傾向に あった(図 1)。

\section{2. 生活環境と衛生管理}

震災直後の避難所の環境について, 表 3 に示した。震 災直後は津波の被害を受けた住民が多く，「ずぶ濡れの 人も避難してくるので被災直後は土足だった」ダンボー ルやカーテンを敷いて寝た」「食べるものが無かった」 「着替えもできなかった」などの発言があり，避難者は 劣悪な環境で過ごしていた．また，「感染症への関心は 低下していた」という発言もあった.

避難者は施設内に常設されているトイレを利用してい

\section{表 3 震災直後の避難所環境における避難者の発言}

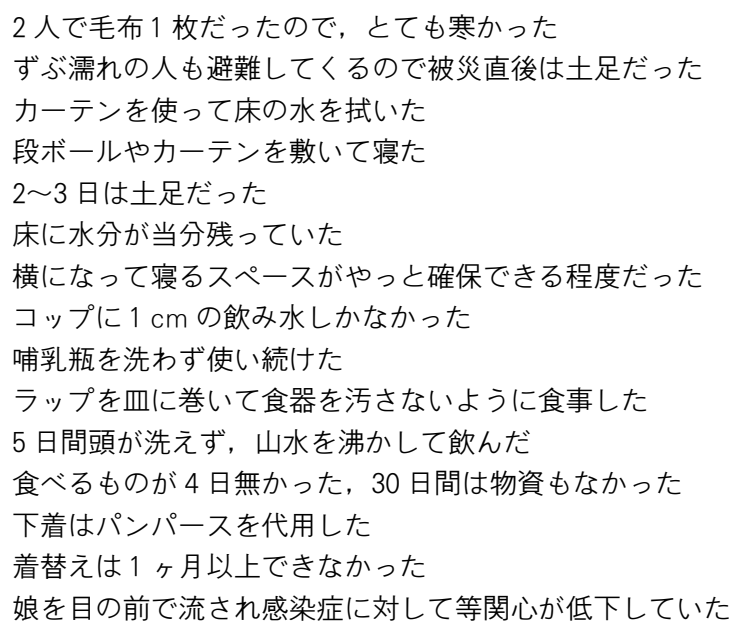

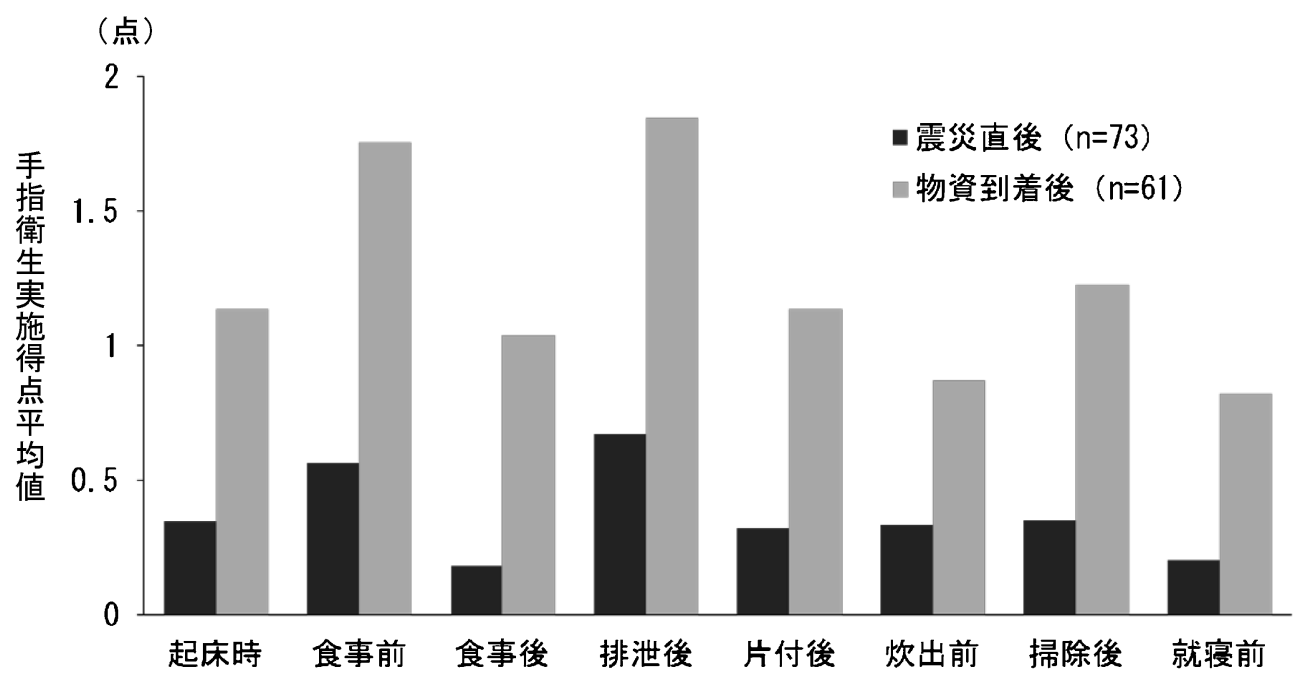

図 1 手指衛生実施場面による震災直後之物資到着後の手指衛生頻度の比較

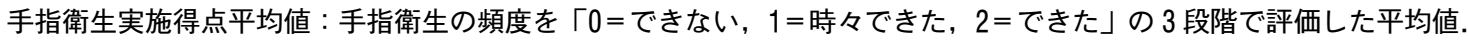


表 4 震災直後のトイレ環境における避難者の発言

トイレが常に濡れていた

プールの水を汲んできて便は流すが，尿はそのままだった 新聞紙に排泄物を溜めて捨てた

庭に穴を掘って便は捨てていた

拭きとり紙はビニールに包んで捨てた

污くて足の踏み場がなかったので，外でしていた

男性が衣装箱をトイレにしてくれた

男は外で空地や車の影, 穴を掘って用を足していた

污物はドラム缶に入れて燃やした

泥水で污物を流した

トイレは行かないようにしていた

トイレは自宅に戻っていた

震災から 10 日後くらいに, 仮設トイレが設置された

\section{表 5 避難所の環境衛生改善に関する避難者の発言}

最初は役場の方が掃除していた

最初は気づいた人が掃除をしていたが，担当者を決めて順 番に行った

数日後に土足禁止にした

住民が交代で毎日掃除，換気を行った

ボランティアがきてから掃除を行った

婦人会の人たちが順番に掃除していた

班長をつくって, その指示に従っていた

拭き掃除を交替でみんなで行った

担当を決め, ルールを作った

町内会の自治会長やPTAの人が声をかけて掃除をおこなった 水が復旧後, 当番で掃除を行った

リーダーがしっかりしてたので，みんなで協力してきれい にした

たが，その環境は断水により「排泄物の処理にはプール などから汲んできた水を使用」するため,「常に水で濡 れた状態」であった。 また, 流しきれない排泄物は「新 聞紙に包んで破棄する」「屋外で穴を掘って埋める」な どの方法で処理していた，その他に，避難者らは「衣装 箱やバケツを改良してトイレ代わりに使用した」「トイ レに行かないようにした」「トイレの時だけ半壊してい る自宅に戻っていた」などの発言があった(表 4).

このような環境のなか, 避難者らは「交代で換気や掃 除を行った」「数日後に土足禁止にした」など, 環境衛 生の改善を図っていた。この時点では班長やリーダーの 存在を発言する避難者が多く（表 5), 掃除は 36 名, 換 気は 27 名がリーダーの指示に従い実施していたと回答 した.

外部支援については, 指導があったと 21 名が回答 し, その指導者は看護師 9 名, 医師 4 名, 保健師 3 名 で「リーダーが聞いてきたことを教えてもらった」と 複数が回答した。指導内容は主に手指衛生とマスクの着 用で, 加えて清掃や感染者の隔離であった. ポスター揭 示があったと回答したのは 10 名だった.

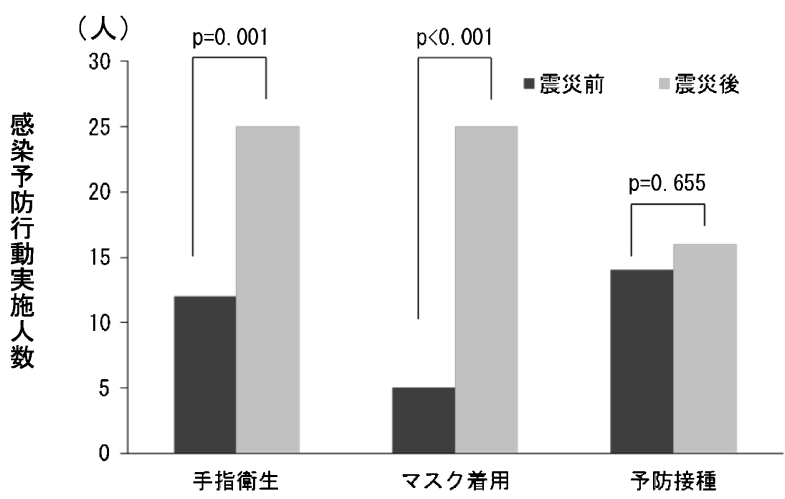

図 2

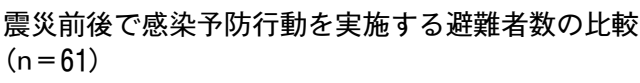

\section{3. 避難者の衛生的な行動の変化}

避難所での個人の感染予防は，「マスクは寒さ対策に もなる」とマスクの着用が 23 名と最多かった. しか し，「同じマスクを使い続けていた」や「日赤が来てマ スク着用を始めた」という発言もみられた。 また，感染 者が出現した場合，「家族内で隔離」を行っていた．

震災前と震災後の手指衛生の実施とマスク着用は, 震 災後が有意に増加し, 予防接種の実施人数も震災後のほ うが若干増加していた（図 2). 震災後は「手指消毒剤や マスクは救援物資でもらったものがたくさんある」と回 答するものが多く，震災当時の救援物資が約 2 年を経 過した今も備蓄されていた。

\section{考察}

東日本大震災において水道が遮断され救援物資が届か ない状況下で $60 \%$ 以上の避難者が手指衛生を維持でき る環境になかったが, 個人で調達できた場合にウェット ティッシュや手指消毒剂を使用していた．救援物資が届 くことによって，手指衛生の未実施率は改善されたが， 飲料水が優先され手を洗う環境は十分整わない現状が続 いた避難所もあった．実際，震災 1 ヶ月後の森下5)の調 査でも, 14 力所の避難所のうち 12 力所は上下水道が復 旧して抢らず，手指衛生はペットボトルや給水車の水を 使用していたと報告している，一方で，水質の保証がな いが沢水や井戸水を利用して被苂直後から流水による手 洗いを維持していた避難所もあった．災害発生時には質 はほどほどでも十分な量の水を公平に供給することが優 先され，衛生上の行動に必要な基本量は $2 \sim 6 \mathrm{~L} /$ 日とさ れている6). 本災害では津波が発生し広範囲に及んだた め, 水の供給は避難した場所によって格差が生じた．現 在，神戸市は被災経験を基に避難所と備蓄倉庫が兼備さ れており7)，このような対策がとれていれば，たとえ道 路が寸断されても一過性の水不足は回避でき, 公平な水 の供給ができたと思われる，手指衛生の実施は救援物資 
の到着や水道の復旧によって食事前や排泄後の場面で高 くなった，ところが，活動制限のある患者を対象にした 報告で, 就寝中の布団の中は細菌を増殖しやすい温度と 湿度になり起床時の手指污染が高まることや，食事後の 手指は食物が付着している可能性が高く手指污染は増強 することが明らかにされている8). すなわち, 手指衛生 は食事前や排泄後だけでなく, 手指污染されやすい起床 時や食後も実施することが望ましいが，避難者は頻繁な 手指衛生には至っていなかった。これは, 被苂後長期 間，手指衛生が全くできなかったため個人の衛生に対す る意識が低下している可能性や, 被害の大きさが手の污 れを気に留める余裕を無くしていたことが考えられる. また，手指衛生のタイミング，石畧使用の有無や手拭き タオルの共用など, 被災前からの個人の衛生的な生活習 慣が影響し, 手指衛生の環境が整ったとしても, 避難者 全員があらゆる場面で適切に手指衛生を実施するとは限 らない。しかし, 災害時は感染症アウトブレイクのリス ク因子が発生しやすいため ${ }^{9)}$, 不十分な手指衛生では接 触感染を容易に引き起こすことになる，そのため, 厚生 労働省 ${ }^{10)}$ でも避難所の生活者や支援者に対して「こま めな手洗いの励行」を推奨している. したがって, 避難 者はこれまでの習慣を超えた手指衛生を実施することが 望ましく，普段の日常生活から手指衛生に関心をもてる よう働きかけ，習慣化しておくことが課題となった.

大規模災害後は衛生状態が悪化することが多く, 避難 者が密集する避難所では感染症のリスクが高まる．本災 害においても，横になって寝るスペースがやっと確保で きる程度の密集環境であった。㷋害直後, トイレは 50 人あたり 1 基を設置し, 慢性期に入るまでに 20 人あた り 1 基のトイレを設置することが国際的なコンセンサ スである ${ }^{6)}$.しかし, 本災害では仮設トイレの設置に時 間を要し, トイレは劣悪な環境で最大の課題となってい た. また, 多くの避難所で散発的な感染症は発生し, イ ンフルエンザやノロウイルス胃腸炎などの集団発生が報 告された ${ }^{11,12)}$.このような環境下で, 感染を予防するた めには避難所の環境衛生を維持することが重要である. 被災当初は行政やボランティアが清掃を行っていたが， 避難所生活が長期化することを見込まれた避難者らは集 団の共通問題を認識し, 解決するために力を結集した.

避難者らはリーダーの指示により居住スペースやトイレ の清掃，換気を実施するようになっていった，そして， 震災数週間後以降の医療機関や行政機関によるサーベィ ランスでは，大きな健康被害をもたらすような感染症の 流行は免れた ${ }^{13,14)}$ と報告している. 黒田 ${ }^{15)}$ は避難所内で 自治会を立ち上げ，会長・副会長の下で避難者が自立す る仕組みを作ることの重要性を述べている．コミュニテ ィ・エンパワメントの構成概念の一つに「住民のリー ダーシップ」16)があるが，本災害において避難者らがコ
ミュニティ・エンパワメントを発揮した結果，避難所の 環境衛生の維持に大きく貢献したと思われる，また，佐 々木ら ${ }^{17)}$ は, 震災前から保健師として市民と一体とな り健康づくりを推進していた結果, 震災後も被災した市 民同土が共同して活動を展開していると報告している. 避難所で一過性に自治を設立することは重要であるが， 災害時の備えとして日常から市民同士の「つながり」を 重視した保健活動を展開しておくことで, 自治が形成さ れ強力な礎になると思われる.

日本看護協会は発災 10 日目から数ヶ月に渡り災害支 援ナースを避難所や医療機関に派遣し，24 時間常駐し て避難者へのケアや感染管理措置の対応などの活動を行 っていた ${ }^{18)}$. ところが, 医療班やボランティアといっ た外部支援者から感染予防について指導があったと認識 している避難者は約 $25 \%$ に留り, ポスターなどの掲示 も認識していた者は $10 \%$ 程度だった.さらに，居住地 が壊滅状態になっている状況におかれた避難者は, どの ような外部支援があったかまでは記憶していなかった。 避難所には多様な支援団体が訪れるため, 詳細な支援の 内容まで理解されていない現状が明らかになった。 しか し, 外部支援による衛生管理の指導は, 環境整備の重要 性を認識し率先して感染予防行動を実施しているリー ダーを通して, 同じ避難所で生活している人に伝達さ れ，定期的な清掃や換気の開始といった行動に現れたと 思われる.

震災の被害を受け避難所生活を経験した人々は，手指 衛生のタイミングが増え，マスクを着用するなど感染予 防行動に変化があった。しかしながら, 同じマスクを何 日も着用するなど䛊った使用があり，日常から正しい使 用方法を伝達していくことが課題となった.

\section{結論}

大規模な災害時では，医療機関は避難所に対しては後 方支援が限界となる，そのため，避難所で感染伝播を防 ぐ対策として，下記のことが明らかになった.

(1)救援物資の到着とともに手指衛生は強化されるが, 個人の衛生的な生活習慣が影響するため, 被災前から日 常的に手指衛生が習慣化する関わりが必要である.

(2)環境衛生はリーダーの存在により維持できるため, 早期に自治会を発足させ，外部支援による指導はリー ダーに伝達し, 避難者の感染予防行動へと展開させる.

(3)震災後, 感染予防対策を実施する避難者が増加する ため, 外部支援者は適切で効果的な方法を指導する必要 がある。

\section{本研究の限界}

避難者が被災当時に体験したことを避難者の言葉で回 答を得たが, 本災害から約 2 年経過してからの調査で あり, 被災体験は長期間で状況の变動が顕著であったた 
め, 避難者は曖昧な記憶が多い。また，衛生管理や感染 予防と認識しての行動や対策ではないため, 十分な回答 を得ることが困難であった，そのため一般化するには限 界がある。

本研究は平成 24 年度「赤十字と看護 ·介護に関する 研究」助成金を受けて実施した.

謝 辞 : 本研究を実施するにあたり，ご協力くださいました東 北地方の保健師, 看護師の皆様に感謝いたします。 また, 調査 の快諾および場所をご提供くださり，貴重なお時間をいただき ました調查対象の皆様に深謝いたします。

利益相反について : 利益相反はない.

\section{文献}

1）西條美恵：被災地病院における感染対策の経験. INFECTION CONTROL 2012; 21(7): 30-9.

2）高橋幹夫：東日本大震㷋に抢ける ICAT「避難所サー ベイランス抢よび避難所衛生支援」活動報告. INFECTION CONTROL 2011; 20(10): 4-12.

3）結核・感染症譲歩センター: 東日本大震災に係る避難 所サーベイランスについて. 宮城県保健環境センター 年報 2012; 30: 52-7.

4) 平成 22 年厚生労働科学研究費補助金「新型インフル エンザ等の院内感染制御に関する研究」研究班 : 避難 所における感染対策マニュアル. 2011 年 3 月 24 日版.

5）森下幸子：災害支援ナースの実践(3)避難所の環境調 查. 看技 2011; 57(12): 119-24.

6）スフィア・プロジェクト：人道憲章と人道対応に関す る最低基準 2011 年版. http: // www.refugee.or.jp / sphere/ : 2014 年 6 月 1 日現在

7）釜瀨真幸, 齋田和孝: 感染予防の視点からみた自治体 の大規模災害対策一被災経験の有無による違い一. 九
州看福大紀 2011; 12(1): 59-67.

8）岡田淳子, 深井喜代子：活動制限のある入院患者の手 指污染度と清潔ケアの検討. 日赤広島看大紀 2006; 6 : 21-7.

9）中島一敏 : 㷋害時の感染症対策一ニーズ評価とリスク アセスメント一。臨とウイルス 2013; 41(3): 156-62.

10）厚生労働省：被災地での健康を守るために 平成 23 年 7 月 25 日版. http://www.mhlw.go.jp/bunya/kenkou/ hoken-sidou/dl/disaster-110722.pdf : 2014 年 7 月 31 日現在

11）遠藤史郎，徳田浩一，八田益充，國島広之，猪俣真 也, 石橋令臣, 他 : 東日本大震災後の避難所に拈いて 発生した A 型インフルエンザアウトブレイク事例．環 境感染誌 2012; 27(1): 50-6.

12）齋藤幸一: 岩手県における震災後の感染症に関する状 況. 臨とウイルス 2013; 41(3): 140-2.

13）金 美賢，神垣太郎，三村敬司，押谷 仁：東日本大 震災の宮城県に抢ける避難所感染症サーベイランス. 日本公衛誌 2013; $60(10): 659-64$.

14）押谷 仁，三村敬司，神垣太郎：東日本大震㷋後の感 染症への対応：何が機能し何が機能しなかったのか． 臨とウイルス 2013; 41(3): 148-55.

15）黑田裕子 : 事例を通して学ぶ避難所・仮設住宅の看護 ケア Case17. 日本看護協会出版会, 東京, 2012, p. 103-4.

16）中山貴美子，岡本玲子，塩見美抄：住民からみたコミ ュニティ・エンパワメントの構成概念一住民による評 価のための「望ましい状態」の項目収集. 神戸大医保 健紀 2005; 21: 97-108.

17）佐々木亮平, 岩室紳也：被㷋地の復旧，復興に不可欠 な公衆衛生機能とは。公衆衛生 2012; 76 (5)：397401.

18）日本看護協会 : 東日本大震災復興支援事業 災害支援 ナースの活動. http://www.nurse.or.jp/home/saigai/ katudo.html : 2014 年 8 月 31 日現在

〔連絡先：=738-0052 広島県廿日市市阿品台東 1-2 日本赤十字広島看護大学 岡田淳子 E-mail: ojunko@jrchcn.ac.jp] 


\title{
Infection Prevention Measures and Hygiene Precautions Among Evacuees in Emergency Shelters
}

\author{
Junko OKadA ${ }^{1)}$, Yukiko YamamizU ${ }^{2)}$, Hiroyuki Yamane ${ }^{3)}$, Mie Yamamura ${ }^{1)}$, \\ Yoshie Matsumoto $^{1)}$, Takeshi Hyakuta ${ }^{1)}$, Mie Saijo ${ }^{4)}$ and Mie Itabashi ${ }^{4)}$ \\ 1) Department of Nursing, Japanese Red Cross Hiroshima College of Nursing, \\ ${ }^{2)}$ Clinical Safety Management Office, Hiroshima Red Cross Hospital \& Atomic-bomb Survivors Hospital, \\ 3) Infection Control and Prevention Room, Shobara Red Cross Hospital, \\ 4) Department of Nursing, Japanese Red Cross Ishinomaki Hospital
}

\begin{abstract}
When a large-scale disaster strikes, medical institutions give priority to a large number of hospitalized patients in critical condition. Therefore, the logistic support for evacuees in shelters receives low priority. Consequently, infection prevention precautions taken by individual evacuees become important. This study aimed to gain a better understanding of such precautions in order to develop measures to prevent the spread of infection during disasters. Structured interviews regarding hand hygiene and environmental sanitation were conducted with 80 evacuees of the Great East Japan Earthquake who had lived in emergency shelters. About $60 \%$ of evacuees reported the absence of facilities to wash their hands immediately after the earthquake. Restored water supply, and the arrival of relief goods, led to improved hand hygiene among the evacuees. However, given the importance of individual hygiene habits, day-to-day involvement might be necessary to ensure hand hygiene precautions among evacuees. We also found that only about $25 \%$ of evacuees were aware of external support for infection prevention behavior and sanitary control guidance. The hygiene environment was maintained in shelters with leaders who had received guidance on infection prevention behavior. This finding suggests the importance of a leader who manages the group in order to prevent the spread of infection. We should provide support to ensure that evacuees can ensure infection prevention behavior.
\end{abstract}

Key words : shelter, evacuees, hand hygiene, hygiene precautions, infection prevention 